Digitized by the Internet Archive in 2008 with funding from Microsoft Corporation 


\section{R H PORT}

O) J II E

\section{BOARDOF A GRICULTURE}

$$
\text { т } 0 \text { ' }
$$

\section{CALIPORNIA STAPEY AGRICLLTURAL SOCIETY,}

$$
\text { A T T } 11 \mathrm{~F}
$$

$\Lambda N N U \Lambda$ II EETINC

January 26, 1865,

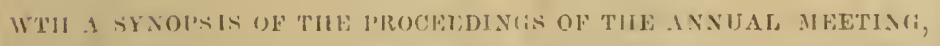
IVU I MEFISG (IF THE आU,IRH.

$$
\text { SAORA ILENTO: }
$$

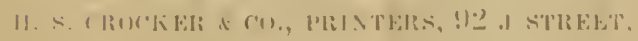

$$
\text { IXiji. }
$$





\section{REPORT}

O I T E

\section{BOARD OF AGRICULTURE}

$$
\text { TO TH L }
$$

\section{CALIFORNIA STAPT AGRICULTURAL SOCLPTY,}

$$
\text { A T T II E }
$$

A N N $\triangle \mathrm{L}$ METING,

January 26, 1865 ,

WTIL A SYNOPSIS OF TIIE PROCEEDINOS OF THE ANNUAL MEFTINa, A.TD A MEFTING (IF THE BOARD.

SACRA MENTO:

I. 8. CROCKER \& CO., PRINTHRS, (1) J STREET, 1865. 
STATE BOARD OF AGRICULTURE, FOR 1865.

President,
C. F. REED.................................Grafton, Yolo County
Directors,

C. T. WhEELER......................................... Sacramento

John H. Carroll......................................Sacramento

Eigar Milis..........................................Sacramento

B. R. Crocker...........................................Sacramento



W. P. Coldeman........................................ Sacramento

A. G. Rrehardion .................................... Sacramento

RoBERT Beck..........................................Sacramento

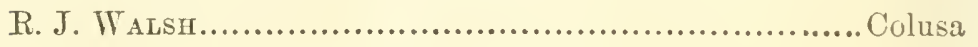

OFFICERS OF THE BOARD

Secretary,

I. N. Hoag................................Yolo-P. O. Sacramento

Treasurer,

R. T. Brow v ......................................... Sacramento

Chemist and Metallurgist,

Dr. R. Oxrand, F. C. S... ...............................San Francisco Geologist,

Prof. J. D. Whitwey.....................................San Francisco

iretcorologist,

T. M. Logan, M. D.................................... Sacramento

$$
\text { Zoologist, }
$$

J. G. Cooper, M. D..................................San Francisco

H. Benr, M. D.....................................San Francisco

Botanists,

A. Kelloga, M. D ...................................San Francisco

Prof. H. N. Borlander.............. ................. San Francisco

Annual Address for 1865, by

JOHN F. MORSE, M. D............................San Francisco 


\section{REPORT.}

Gentuemen :-This being the rear in which no report to the Governor is required by law, the Board will reserve a mole detailed report of the year's transatctions nutil the proper time shall arrive, and proceed to give to the menbers of the Society a brief account of their stewariship', and to make such sugrestions and recommendations as their experience and the condition of the Soriety and the State seem to demand.

One year ago, when we assumed charge of the affairs of the Society, it was at the close of a year of prosperity to all classes of industry in the State. The agriculturist had been blessed with a plentiful havest, which had enabled and induced him to prepare for an extensive field of operations, with hright hopes that his renewed efforts wonld again be crowned with success. The miner, in adclition to extracting from the placer deposits and quartz ledges the usnal quantitios of the precions metils, had extended his discoreries and dereloped new regions of mnusual richness, and was confident in the prospect of a year of unequaled prosperity. The mechanic, the manuficturer, and all other clisses of the community dependent on the two former for encouragement and support, hal received a corresponding impulse and were looking forwal to the new year cheered with confidence atud hope.

Under the judicious and economical management of our immediate predecessor's, the financial condition of the Society had been much improved. A portion of a large sleht which had been allowed to accumulate anganst the Society dnring a series of previous years had been cinceled. A change of administration hatd, to a certain extent, checked the increasing dissatisfaction and want of entidence, so prevalent in the community toward the Society and its management. Under these cireminstanees, and with reliant expectation of material aid from the State, the Boarel met on the 9th of February, and by manimons vote resolved to hold a ureneral Fair of erepry Departmont of Ludustry of the State in the following September.

The Lerislature, then in sesion, contrary to onr expectations, and, as we think, acting 1 pon a very short-sighted policy, withhold tho usual appropriation for tho pityment of premiums. 'Tho 
murl, hoperl-for rains, which had been deferred during the Winter, failci to fall in the Spring, and it soon become rery evident that all the industrial interests of the State, which had but at short time before seemed so promising, must suffer materially, if not prove to a great extent a failure. LThe Board. theretore, rather than risk a general Fair, with so poor a rrospect of a creditable exhibition, and with almost a certainty of a tinareial disaster. reconsidered its furmer action, and determined to conform its operations strictly and rigidly to the ciremmstauces in which the state and the Society were placed. The latw, howerer, establishing the Society and creating the Board of Arricultmre and defining its duties, as well as the tenure by which the Society holds some of its most raluable property, required that a Fair of some description should be hedd. In an ordinary season. to select one branch of industry, howerer attractive or important-and bestow upon it the fatronage and encouragement of the Socicty, to the neglect of all others, wonld be as minise on the part of the Board, as it would be unjust to those branches neglected. The effects of the drought, however. upon the cereals, and all the various crops of the husbanduan: the scarcity of grazing for stock, compelling the owners of cattle and shcep to drire their herds and flocks to distant portions of the State and out of the State for sulmistence; the empty treasury of the Societr aud the general scarcity of money among the people, admonishing the Board of the propriety of a light bill of expenses, all plainly indicated the chilracter the Fair should assume in order to render it, even in one department, a success.

It was erident that no other course than the one pursued conld, with safety to the existence and future prosperity of the Society. be adopted, aud even as to this, the Board was in doubt.

At this period of attairs, the citizens of Sacramento, with a liberality equaled only by their enterprise and persererance, came forward and, by subscription, placed at the disposal of the Board orer fire thonsand dollars, to be awarded as purses and premiuns for a horse slow.

The sum of ais thousand nine hundred and thirty dollars were oftered in prenimms and purses, so distributed as to render the exhibition a feature of attraction and a lesson of usefulness to the admirers of all classes of horses, from the sturely dranglit. to the flect and heautiful thoronghbred. All preparations were carefully, eromomically and well completed. and the Fair was held. It juroved an success in ercry respect beyond the most sangrnine exjertations of the Bosurl. "The maxim that "whaterer is worth loing at all, is worth doing well," having been alopted in the begiuning, it was strictly arlhered to in every particular. The very liberality of the purses, and peminms offered, gare tone and character to the exhibition. The high falne of the stakes to be last or won gave everybody the inpression that the lair 
must be a crand sureess, and no one went away disappointed or dissatisticel. 'The superiol srate and quality of the stork on exhilition, indieates the rertain and prositive improvement we aro

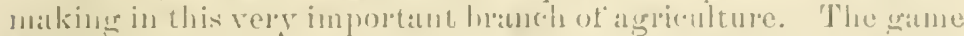

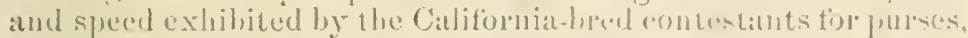

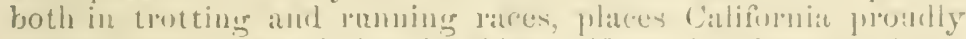
upour the turt record, hy the side of, if not, in aldratee of ally othere state in the Union. Indeed, we think we maty be permitwed to sily that the Far of the State As sicultural Society of lotit, taking all things into consirleration, has formed one of tho brightest pages in the listory of the turd, and rerr juminenty foreshadows many brightor ones for our State and the Society in the finture.

While we coneratulate the members of the Societr mpon the many happry and useful lexsons of the Fair as an exhibition, we are also galad to be able to inform them that, notwithstandiug thes extreme unfirorablenciss of the stason, it bats proved an unprecedonted financial suceess. brery premium aml purse wero promptly paid als soon as awaded or woll, amb eren more than were oftered. Frery item of expense male and anditerl by tho Board has been promptly and satisfactorily canceled. 'The handsome sum of $\$ 8,41272$ of the old indebtedness of the Society hits been discharged, learing the present inclebtedness, including interest to January $13 t h, \$ 11.33+6.5$, against $\$ 26,47: 36$ on the

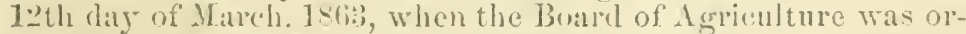
ganized and the aftirirs of the Suciety were plateed in its latnds.

When we take into consideration the embarrasiner circumstaners, both peemiarily and otherwise, in which the society wits found to be at that time, and the diffeulies it hats enconitered and overeome since, and that it has still been able to work out, in less than two years, this substantial financial result, and regain to so large an extent the contidence and good will of the community, we are forced to the conviction that, with the enormelous receipts of former years, the Society should to-day latre ocenpied a very different josition among the useful instiutions of the State, trom the one in which we find it. Insteacl of being poor and its energies crippled with the incumbrance of at larewo debt, it slould hare been in the enjoyment of - moh means and ficcilities as would have enabled it to exert a jowerful intluenco in the direction and development of all the matcrial interests of the sitate.

The mineral cabinet of the Society has not received so sieat accessions during the last, as during the preceding yate, owing to 1 he general depression of the mining interest, following the unlealihy excitement of 1862 and 1sti:i. Lowerer, many valuahle specomens have been adeled to the collection. The imalor County Arricultural Socicty has domazted a ralhinet of orer aw thonsind specimens, mostly fiom the valuable coppor mines of 
that county. And Amador elaims, and is entitled to the distinction of being the banner comnty of the State, as regards contributions to the State Society's Cabinet.

Most of the newspaper's and periodicals of the State, with a liberality not shown by the press in any other part of the world, have rontinued to furnish the Socicty.with their regular issnes. All these have been carefully filed away and preserved, and when bound will constitute an invaluable portion of the Society's library. It will contain a most complete general and local history of the State and its interests. The contributors are entitled to the thanks of the Board and the Society. And hele we would also say that the California Steam Navigation Company, Wells, Faugo \& Co., and the various stage and railroad companies in the State, have, by their miform liberality: placed the Society under lasting obligations. Taluable contributions of statistical reports of rarious departments of the General Gorernment have been received from our Senator, John Conness, and Representatives Higby, Cole and Shannon. The Society has also heen the medium of the above named parties and Isare Newton, Commissioner of Agriculture at Washington, for the distribution of a large number of the annul and bi-monthly reports of the $A$ gricultmal Department, as also of many varieties of new and raluable seeds. The latter have been given out to parties who have promised to exhibit the products, by sample, at the sueceeding Fair; but owing to the drought, very few of those distributed last Spring have been heard from. No seeds, except a few packages of wheat, have been receiverl yet this season. Tegetable seeds are nsually received too late for use the same year, and hence many varietics are damaged by are. The attention of the Department has been called to this fact.

We are under obligations to B. B. Redding, Secretary of State, for Statutes of 1863-4; to W. C. Stratton, State Librarian, for Journals and Appendix of the Assembly and Senate; and to C. W. Wyman, of Massachusetts, for six volumes of the Transactions of the Massachusetts State Board of Agriculture-a valuaable contribution.

The Society's reports for 1863 have been published and distributed throughout our own State, and many copies mailed to leading jomrnals and agricultural and other industrial societies in the Atlantic States and Europe. Correspondence has also been opened with these institutions, with direct reference to increasing the size and usefulness of our library, and the Board confidently anticipates satisfactory results.

The Constitution of the Soeiety has not been amended since the passage of the law creating the Board of Agriculture. To make it conform to the change in the management of the Society, some alteration will be necessary, and perhaps no time more appropriate for making such alterations will be found than the 
present meeting of the members. If the Society should conclude to make such alterations, the Board will suggest some additional ones, which, wo think, will tend to enlarge the sphere of its nsefulness, and to render its published transactions more practical, and give them a more reliable and anthentic character. It has formerly been the custom of the Directors of the Society to atppoint Visiting Committecs. Who have traveled at great expense to the Soriety, on exploring experlitions, the scope of their observations embracing every department of industry through the whole length and breadth of the State, and even into adjoining States. These Committees have reported to the Board, for embodying in the published T'ransactions, with tiresome minuteness, where and how they went, and all they saw.

It is cloubtful whether the benefits derived from sinch a custom are equal to the necessarily great outlay. It is believed that the oljects for which the practice was instituted may be attained in a much more reliable and authentic manner. and with comparatively little expense. There are men of ability and practical experience in each particular branch of industry, in every part of the State, who would, no doubt, if requested, bo willing to act as ofiicers or Committees of the Board, in collecting and reporting to them, annually, fucts and useful and reliable information in the particular department for which they are qualified and for which they should be appointed.

Wo have groologists of high character and standing among us, whose business culls them to a constant investigation of the geological structure and advancing development of our mining regions, and whose opinions have great weight, both at home and abroad. Let the Board appoint some one of these as the geologist of the Society, and ask of him a practical report of the character of our different mineral sections, and the prosress and improvement annually mate in mining. Such reports would be, of course, brief and adapted to the general reader, and being published in the annual trimsactions of the Society, would reach at class of readers who would never see the claborate reports of the State Groologist, now in process of publication. And here we think it not improper to remark, that while the General Grovernment is directing its inquiries and investigations to determine in what manner to manage or dispose of the public domain embrated within that portion of our State usually denominated mineral lands, so as at once to produce the greatest revenne to her treasury, and be of the most benefit to the oecupants of the same, perhaps it might be well to inquire what the effect upon the finture wealth and industry of the State wonld be were thoso lands to be disposed of in such a mamner as to invite and indueo the permanent oceupancy and cultivation in rineyards, of those millions of acres located on the hill and mountsin sides, and in the countless valleys, which, from actual experience and by the 
chemical analysis of the soil and the farorable atmospherical phenomena are proved capable of producing wines and raisins equal, if not smperior, to the most excellent productions of the most favored wine-producing comtries, not excepting the celebrated wines of the Johannisberg and delicious raisins of Malaga. Under our present system of mining regulations and la $5 \%$. very few of these acres will be thus cultivated until the title to the same is rested in the cultivator. Their management or sale becomes a serious question of State as well as national policy. It is the interest as well as the dnty of the people of the State to indicate to the General Governinent the proper policy to be adopted in regard to them. It is better to take time by the forelock and control and direct that policy for our own interests and the best interests of the Gorcrument, than, when too late, to condemn a policy which may be to the detriment of both. Every department of industry is equally interested in the question, for when yon touch the mines with the hand of oppression you oppress every other interest, and when you encourage and stimulate the derolopment of the mines, you encourage and stimulate every other pursuit. In this respect, if not in the actual investment of money, we are all miners and all cultivators of the soil. A Convention, embracing all the States and Territories on this side of the continent, called during the ensuing Summer, for the discussion of this subject, might lead to good lesults.

Our wine-making interest is becoming one of the greatest industrial interests of the State. It excels that of any other State in the Union. Yet there is not perhaps another branch of industry, in regard to the practical operations of which, there is so much ignorance among our people as this. The varieties of grapes best adapted to wine-making in our State, or in the different localities of it; the chemical properties of the soil required for superior wines; the atmospherical intluences of different localities; the manuer of planting the rine and tilling the rineyard; the gathering and pressing the grape, and fermenting and after-treatment of the juice or must until it is converted into wine-are all subjects about which our people have but very little practical or satisfactory information, and upon which there is prevailing, in all our agricultural communities, the most lively interest and intense desire for knowledge.

If the Board were to appoint some competent person as a chemist to the Society, who wonld, under its sanction and in his official cliaracter, receive and analyze for a fair compensation, to be paid by the applicant, the soils of different localities, and the juice of grapes grown in the different wine-growing distriets, and keep a careful record of his operations, to be reported to the Board, and if at the same time they were to enlist in their serrice, as Committeemen, intelligent and practical cultivator's of the 
vine and wine manufacturers in the different localities, who should also report their observations, experience and opinions to the Boarl, all to be embodied in the published transaretions, they might perhaps be able to form some well defined landmatris, which ma serve as incentives to enterprise, and guides in tho prosecution and development of this great resourec ot wealth and prosperity. If suceessful in the aceomplishment of this object, tho bociety would have rendered a survice to the people and the state greater and more lasting than if, by somosmpernatural power, they wero to convert the whole bulk of Mount Diablo into gold dollars and distribute them equally between every man, woman and child within her borders.

'The present anomalous eondition of the general stock-raising interest of our State may well attract the serious apprehension of and engage the attention of the political economists and the best husiness minds among us. The amual record of death by starvation of a Iarre percentage of the stock of our State, hats become almost as much a matter of eourse as the periodical return of our rainy seasons. During the unusually dry season of the past Summer, a great number of stock were driven to the momntains of the Sierra Nerilda and Coast Range, where they found an abundance of food to carry them safely through the dry season, but to return to tho ralley ranges to enrich the soil with their deeaying eareasses. Many others were driven to the low land surrounding the confluence of our large rivers, where sufficient feed for the subsistence of nearly halt of the stock in the State, dnring the Summer seasons, has for years fast been allowed to ro to waste :mmually; but, when forced from these luxuriant fields, by the sudden rise of the waters, the same destructive fate awaled them as did those from the mountains. The last was an extraordinary season, it is true, but if the owners of large herds of stock would pursue the same courso in ordinary seasous that they rlid the last they would make a eroat improvement orer the usual eustom of pasturing them on the same ranges during the Summer on which they are compelled to keep them during tho following Winter.

But to reform and correct the evils and drawbacks attending stock raising seems to require a pretty thorough rovolution in the whole farmtng system. The owners of largo herds and flocks will be rompelled to reduco then to such it number as they can provide Winter food for ; and the firmers who hare heretofore turned their attention almost exelusirely to grain raising, will find it mueh more protitable to raise in greater rariety of crops, and include in their anman sales of the products of the farm, a few young horser, fat cattle, sheep and hous. The statement of two or three facts, will scrve to illustrate the extraordinary and disastrons condition of this branch of industry, as it is now seen. During the last Summer 
when it beeame evident that the hay crop in a large portion of the State must prove a failure, and consequently command a high price, many persons resorted to the tule lands at the mouths of the San Joaquin, Sacramento and Cosumnes rivers, in search of the desired article. Here they found thousands of acres of natural meadows, upon which were cut and secured, according to statistics collected by the Secretary of this Board, and careful estimates made by men of good judgment engaged in the business, not less than fifty thousand tons of a very fair quality of hay. According to the same estimates, thore were left standing uncut at least an eqnal amount. Yet within sight of these extensive mearlows, much of them unclained and unappropriated by anybody, large flocks of sheep and herds of cattle have been reduced by starration since the rainy season commenced from twenty-five to fifty per cent. in numbers, and probably thirty-three per cent. in the weight of those yet alive. Again, when this hay was cut and freighted to localities where princicipally demanded for use, the expense upon it per ton, as a general thing, amounted to more than an ordinary stock cow or bullock would sell for, and consequently to Winter such an animal upon it, would cost more money than the animal would sell for when wintered.

These are extraordinary eases in an extraordinary season, but to a certain extent they occur every year, and to the full extent may occur again. To prevent such recurrence, and to bring about a lealthy change in the management of this branch of agriculture, are objects worthy the attention of those who may hereafter control the transactions of this Society and the economies of the great interests of the State.

The rast amount of staging on this coast, and the transportation of goods and machinery from navigation to the varions mining localities in this State, Nevada and the surrounding Territories will, until such times as railroads shall superserte these modes of conreyance, continue to create a great demand for valuable horses and mules, and large quantities of grain for their subsistence. To raise a horse or a field of grain may not generally require a greater legree of slill than is possessed by any ordinary farmer: But to raise and prepare for market a large number of good horses with profit to the owner, and well adapted to the business for which they were intended, requires a good degree of knowledge of the principles of breeding. the economies of feeding such animals, and the judgment to apply such principles and economies for the attainment of the end in view.

To make a given number of acres of land produce the largest amount of grain and other food that it is capable of producing, without deterioration of the soil, for a serics of years, requires a much greater degree of skill and scientific knowledge than is usually exercised, at least by the generality of farmers in this country. 
The truth of this latter statement will bo apparent when it is proved, as it has been, by statistics collecterl by our Secrotary during the past year from reliable sources, that most of the grain land in California will, when Summer-fallowed, froduce eighttenths more grain per acre than when plowed andsown after the rainy season sets in. Yet not one-twentieth of the land levoted to grain raising for years past has been summer-fillowed.

It is proper to remark, however, that gruat improvement in the manner of preparing the soil and putting in the seed this season orer past years is manifest in every part of the State. 'The efrorts of this Board, through its Secretary, in calling the attention of farmers to the importance of this sulject, and the drought of the past season, have both contributed to this change. It is hoped that hereafter grain raising will be conducted with greater economy and upon principles which guarantee greater and more certain success. As another gool eflect of the dronght may be mentioned the interest it has awakened in many pal'ts of the State upon the subject of irrigation. The experience of those who have practiced irrigation for a number of years past, proves that most any of our lands situated back from the rirer bottoms proper, and which have heretofore been considered capable of producing only small grains, and these only in farorable seasons, may, by the judicious use of water, be marle to produce in abundance and with almost absolute certainty, most any erop embraced in the husloundman's rocabulary in any climate or country. This experience has also estsblished another important fact that the best and only time necessary to use this watel is during the Winter season, when all our creeks and river's are full and capable of supplying almost any quantity desiled. A thouongh saturation of the soil at this time serves to mature any crop, or two or three different kinds of crops, in a season, withont further irrigation. The people of the counties of San Joaquin, Los Angeles and Yolo have been the first to avail themselves of these important lessous upon an extensive scale.

C. M. Wreber of San Juaquin county, has, during the last season, introduced water over his own land, and that of some of his neighbors, with the most sinatifying lesults.

The particulars as to length of canal or amount of land that may be irrigated have not been received, though written for some time since *

* Note.-The Secretary receirel on the day after the annual ineeting, from Dr. Holden of Stockton, a letter, of which the following is an extract, and which supplies the information written for:

"I lave ascertaineck some interesting facts in regard to the profitable results by irrigation tiom Captaiu Weber's ditches, which are supplied by water trom. the Calaveras until June, the month the river usurlly dries up. "The several ditches run about five miles and irrigate about wo thousand acres, or t(n furms, small sections of which were list year cultivted to wheat: the balauce produced oat hay, and a superior article. The estimated value of crops 
By means of a ditch and reservoir, eleven miles in length, tapping the San Gabricl river, in Los Angeles county. Horty thousind acres of land which has been hitherto userl only for grazing purposes, is now being irrigated and converted into one of the most rertile portions of that county, already so justly celebrated for the rariety and excellence of its productions.

In Yolo county there are fire main ditches, tapping Cache creek in as many different places, with an aggregate length of twonty-fire miles, besides a great number of branches, all capable of irrigating at least ono hundred thonsand acres of as good land as the State contains. Nicholas Wycott, the engineer, who located inost of the ditches in lolo courity, and the encrineer of Swamp Land District No. 18, Iying mostly in that county, says, in a letter to the Secretary, "the day is not fitr distant when the waters of Cache and Putah creeks. in ordinary seasons, will be nsed upon the land, and not be suffered to yass into the tules, except at high floods-thus assisting to reclaim those raluable lands.

The people of Colusa county are also moring in this matter. They propose to take the waters from the sucramento river, at any point above low water mark, so as not to interfere with mavigation, and turn it through a canal which, including one main branch, will be one hundred and twenty miles in length, over an area of some three hundred thousand acres of black ralley land in that and the northern part of Folo county. The scheme is pronounced entirely practical by competent engineers who hare made the preliminary survers, and the people are determined to accomplish the enterprise and reap its benefits. In view of these facts, and the probability of other similar enterprises, may we not look forward to the time when most of the surplus waters of our creeks and rivers during the rainy seasons will be used to irrigate and render immensely productice all the higher lands of our ralleys? As a secondary though rery important result of the accomplishment of such a system of irrigation, great assistance would be rendered in permanently reclaiming the tule lands, and the improvements of our farmers, and the towns and cities on the immediate banks of the rivers would be thus relieved, to a great extent, from danger by overflows.

The mechanical and mannfacturing industries of the State, though partaking of the general depression of the past year, and suffering somewhat from the state of the currency, which

on the two thousand acres is $\$ 25,000$, and without irrigation the crops would have been an entire failure. The above is the only system of ditches for irrigation in this county. The result of this first atiempt of irrigating on a large scale lias been so profitable and sure. many other enterprises of the kind will be undertaken in this county. Californians will find out in time that water is not only quite necessary, but the cheapest fertilizer." 
has encouraged importations, lave, notwithstanding, contimmed to enlist in their proserntion a gratifying incerease of cappital, amel to extend their enterperives and scope to a yreat variety of the articles necessarily used in earying on the rarions inclustrial pursuits, and in supplying the necessities and luxuries of every department of life.

Leather of the various kinds, boots and shoes, harness, faddles, whips, every description of cordage, building materials, granite, matrble, lime, plaster, cement, wayons and carriages, pailroad. passeuger and freight cars; woolen goods, such ats blankets of all kinds, flamels of erery description, cloths and cassimeres, carpets; hats, caps and various kiuds of clothing; shlue, asphaltum, gunpowder, matches, tar, pitch, resin, mincial faint, npirits of turpentine, salt, soap, yeast powdern, starch, vinegar, pickles, evely variety of preserved fruit-, jams, zasisins, fins, macearoni and vermicelli, castor oil, petroleum, wines, brandies and the various kinds of spiritous and malt lifuors; paper of every variety; glass hottles of all kinds demanded, earthen and stone walle; wood, tin and wire ware; mining, mill and steamboat machinery, and machinery of every lind in usc; agricultural implements and varions other articles are manufuctured in the State with greater or less suecess. V'ery many, in sufficient quan tities to supply the home demand and kecp up a very good and remunerative export trade, while others are strugghling anginst the persevering competition of importation.

Preparations, mpon extensire scales, are now being made to add to this list, ritiload locomotives, shot, and lead pipe. The experiment of smelting copper lats alrealy provel so much of at success as to warrant the confident expectation that all our eopper ores will soon be smelted within our State, and thus producea completererolution in our coppermining interest. The experience of nations froves that no classes of industries aid more in enriching and rendering a State independent than mechanies and manufactures. California has greater natural facilitien for becoming an extensive manufacturiug Sitate than any nther in the Tuion, and her icolated position furnishes a strongr reason fin fosteringrand encomaging them.

For the advancement and improvement of all these oljects, ambl, indeed, all the industries of the State, was this Society instituted. While the holding of ammal fairs, at whirele the products and improvements of every department of industry are exhibited for comparison and instruction, atud to stimulate emmlation and enterprise, is calcenlated to do rremat grood, and slould therefore he continued; yet, for the financial suceess of the So-

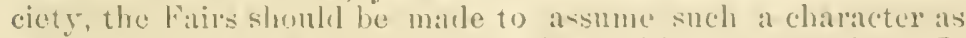
will prove at once the most attrative amel least expensive. It shomlid he no grouml of complaint shomld the Boird aldopt this policy. 
There are other and less superficial merliums through which, in addition to the one just named, the Society may render i'self equally beneficial to our present population and their material interests, and enlarge and extend its sphere of usefulness, so as to enhance more perceptibly and certainly the State's future jrosperity.

Among these may be mentioned a means already adverted to, the appointment of competent Committees to inrestigate and report npon the present condition and best means of improrement in each branch of industry. These reports shonld assume the character of short, practical, and to some extent scientific, treatises, wholly Californian in their character and application. The Society should also own an experimental farm, with all the facilities and appliances for practically teaching and illustrating agriculture, in all its branches, as adapted to the peculiarities of our soil and climate. It should possess an extensive mineral, mechanieal and agricultural museum for illustrating our natural history, our mineral riches, and our advancement in the useful arts and sciences. It should enjoy the advantages of a philosophical and chemical laboratory and an extensive library of useful and practical knowledge, for exemplifying and explaining the truths of science as applicable to the rarious industrial pursuits of life.

Add to these, by authority of law, the facilities of collecting agricultural and other important statistics, in an authoritative and anthentic manner; and the Society would then occupy that position of usefulness for which it was originally organized, but to which few such societies attain for want of some definite aim and some constant and stearly hand to guide them.

The official management of the Agricultural Societies of New York and Missachusetts have respectively been nnder the control of B. P. Johnson and C. L. Flint almost since their first organization. These Societies, either of them, are an honor to any conntry or nation, to say nothing of the States in which ther are located.

The importance of reliable agricultural and other statistics to the successful and intelligent conduct of a Gorernment, and to the advantageons direction and development of the resources of a State, are too obvious to require an argument; and particular$1 \mathrm{y}$ so in a new State, with resources so diversified as ours-and yet we regret to record the fact that we have not now, as a State, and never had any system by which such statistics have been or can be collected. In older and more thickly settled communities, with their superior facilities for communication, it has been found practical to collect such statistics, through roluntary agents, who, without compensation, except the consciousness of nerring their conntry, devote their time and energies to the subject, and, under a system of reports to one common head, 
produce a result sufficiently correct for all practical purposes. But in a State where the facilities for travel, except on greneral routes to a few important localities, ane so limited and ex]ensive as in ours, and where so few of our firmer's have become so permanently fixed and devoted to their occupation as to inspiro that interest in the cause necessary for such an undertaking, and so few are alle to aflord the time and means for its fuithful execution, such a system will be fomnd, as it has already been found by the last two years' efforts of this Board, almost totally inoperative. The present system of reports by the County and District Assessors to the Surveyor General has proved to be equally mreliable and uncertain. Only from one-half to two-thirds of the counties in the State being reported at all, and these repolts in many instances being mere rough estimates instead of actual and careful counts. Statistics thus partial and unreliable, in the opinion of the Board, tend rather to depreciate the value and magnitude of our industrial resources, and to injure and prejudiee the importance and standing of our State, both among our own people and abroad, than otherwise.

Without narrating the history of the eflorts of this Board, during the session of the last Legislature, adrised as they were by our immediate predecessors, and seconded by every District and Comnty Agricultural Society in the State, to rectify these erils, and to obtain the passage of a law which would in our opinion have provided an efficient and etlective system by which reliable statistics relating to all our industries and productions would have been obtained, we will renture to express the hope that our next Legislature will take a more practical and comprehensive view of the material wants of the State, and will comprehend and supply the neeessity of a system by which through the proper ehannels, we may possess ourselves of a full sheet exhibiting all our productions and our present and future capacities. One short Statute that would effectually accomplish this object, would be of a more real and lasting benefit to our State than a whole rolume of such laws as usually emanate from each session of our Legislature. Upon this subject and the neressity of State aid to Agricultural Societıes, Dr. E. S. Holden, President of the San Joayuin District Agricultural Society, than whom no man in the State understands the State's necessities better, holds the following language in his last annual address before that Society:

"Last year this Society, torether with sereral other similar associations, petitioned our Legrislature to appropriate a few thousand dollars for premimm money, but our solons fitiled to see the benetit of such appropriations; they failed to see that three-fourths of their constituents were producing by the sweat of their brows their rery existence, their bead and butter. But there was one thing they conlel easily comprehend, and that 
was the ralue of bribe money to create and airl a host of rascally franchises, yourly springing up from Sin Diego to Siskiyou, from the Sierra to the Pacitic.

"Farmers and mechanics, protect your own interests-those interests which contribute so largely to the wealth and independence of nations. Elect, as it is in your power to do, legislators who ean comprehend the interests of Agriculture and IIanufactures, and who will honestly protect them."

With all these appliances and facilities for usefulness, well managed, the publislied reports of the transactions of the Society would become most interesting and authentic exponents of the agricultural capacities, the mineral wealth, the manufaeturing enterprise and the general resources of the State. Distributed among our own people, they would furnish constant incentives and raluable guides to improrement. Distributed in the Atlantic States and in the rich and populous countries of the eastern continent, they would serve as the most economical and effective agents to attract immigration to onr State that conld possibly beemployed. Teach the skilled cultirator of the rine and the experienced manufacturer of wine, in the agricultural portions of Germany, France, Italy and other old wine-growing countries, that the wine crop has never proved a failure in California since its first introduction by the priests, 150 years ago-that owing to the peculiar adaptation of the soil and climate of our State to the growth of the rine, and the arerage amnual product per acre, here, under good cultiration, is six hundred gallons, while that of the German States and France is not orer one hundred and serenty-fire, and that of Italy-the best wine-producing country in the world outside of California -is less than four hundred and fifty gallons. Teach them that there is in California over twenty milions of acres of the very best of land for vineyards. and that each head of a family can become the owner of one hundred and sixty acres of the same, by coming here and settling upon and improving it-and will not such information, renclered anthentic by our official reports, turn their heads towards California? Will they remain longer than necessity compels them in their own country, where but few of them have any interest in the soil and ean obtain but it poor sulsistence as the reward of their daily labors? Teach these facts to forcign capitalists, and enterjuising and skillful manufacturers, and ther, also, will seek our shores for the profitable investment of thein means, and a more adequate return for their enterprise and skill. We should soon have springing up in the rarions fitvorable localities in our State extensive winerellars, the owners of which would purchase the grape or must frorn the producer, and after suljecting it to careful and skillful treatment for the proper length of time necessary to convert into an article of that snperior quality rendered susceptible by 
the unequaled wine properties of the grape, and not till then, it wonld be found in the market for sale and Gonsumption.

The immediate effects of this change in the management of our wine interests would be a certatin and reliable increased demand for the grape and must, and a proportional increased production. 'The mere grape juice, of from foul to six montlis of age, mado by those professing but rery little skill in its manufacture, and possessing perhaps less, would disappear from anong us, and our home and foreign demands would be supplied with the various kinds of wines, equal, if not superior, to the most excellent and hight-priced foreign brands.

A very large portion of the sugar consumed in the southern countries of Europe is now manufictured in France from the common white sugar beet. It is al demonstrated fact that this article can be produced in rich allurial soil of our valleys and tule land in greater quantities per acre, and with less labor, thin in any other portion of the civilized world. By chemical analysis, seience assures us that, owing to the peculiarly furorable properties of our soil, the California production possesses a greater quantity of saccharine matter than the same alrticle producel in any part of France. 'Taken in conncetion with the frresent and prospective high ruling prices of sugar, we have here another branch of industry pronising a liberal compensation for skilled labor and a munificint return for the investment of capital, managed and direeted by the lights of science and practical experience.

'The cultivation of silk also, by the experience of competent judges, for some ten years, in our State has proved to be a perfect suceess. The mulberry tree flourishes here with a luxuriance known in no other country. The absence of moisture and explosive electricity in the atmosphere, during the scason of feeding and hatching the worms and securing the cocoons, are circunstances which render our State more fivorable for the prosecution of this pleasant and important branch of industry than any other country in which silk is produced.

It is a historical fict that the seasons in the principal silkproducing countries in the south of Europe lave for years past been growing more cold and moist, and hence less firvorable to the production of silk. These are significunt ficets, which may very profitably be taken into accomnt by those who alle to control the future material destiny of our State. It may not be improper here to state that J. Morenhont, Consul of Wrance at Los Angeles, lately sent fire samples of cotton produced in that comby by ats many different persons, to the Minister of Agriculture and Commerce in France, who, after having the sime carefully examined by competent judges, returtued in his official report that the simples were all identical in quality, and would command then about the same price as the short sille cotton of 
the Sonthern States, from $\$ 62$ to $\$ 63$ per one hundrerl pounds. The experiment will be thoroughly tested in that comnty this year. By experiments extending through a series of rears in rajious parts of onr State, it is conclusively proved that raisins, fige, almonds, prunes, olives, all articles of commerce, and consequently not liable to orerstock any market, can be produced here in equal perfection and greater abundance than in any other part of the world. In a rord, to sum up the foregoing statements, we may say we know we lave within our borders the elements of greatmess and prosperity (onul, if not superior, to those of any other State in the Tnion. Then, what do we lack? what do we need? The answer most emphatically is, labor and capital. We cannot attain material greatuess or prosper well without these-without both; and capital for investment in our material resonces will not, for obrious reasons, precede labor, it would follow. Then labor is the first great necessity. And how shall we obtain it? The General Gorernment, through agents and the distribution of farorable information. is wisely and successfully exerting her means and enerchies to induce emigration to the United States. According to the report of the New Tork Commissioners of Immigration, the number of immigrants that arired at that port during the eleren months ending the 30 th of November, 1863, was 146,519. against 76,306 during $1862-$ - showing an increase in one year of nearly fifty per cent. from extra exertion. But loes the Pacific coatst or Califoruia receive any portion of that immigration, or any immediate henefit from it? Tery little, if any at all. The moment the new comer sets foot on shore at Xew York or any other eastern port he is hureied off to Illinois. Indiana, Iiansas, or some other new State east of the Rocky Mountains, but nerer to California; hence, those States, with far less natural adrantages, except as to convenient location for immigration, outstrip us in the race to wealth and general prosperity. The Pacific Pailroad will, when finislied, to a certain extent remore this barrier which now isolates us from the great center of our country's population. But till that time Califormia must work out the problem of increasing her labor and capital, and of dereloping her own resonrces herself. Let California bestir herself, if she would not fall back from her present relatire position among her sister States. Let her make independent and extra exertions to induce a tide of immigration to set in toward her shores before that great field for enterprise and improrement is ojened up in the Southern States, to attract and hold the tide from her. Let her send out. through the Golden Gate, such a flood of reliable information in regard to her mnequaled productions, her inexhanstible resonres and capacities, to those great beehires of industry in the Old World as will canse a lively swarming out of their families of workers, so intent upon securing the un- 
equaled benefits within their grasp here, that no half-way port will attract them from their destination.

Why should not the route firom the rarious emierratiner ports of the Old World to San Francisco, ly way of l'anama, heeome the line of attraction and travel to those who alre secking ath asylum and in lome in America? Bring this about, and onl milleh is onward, our destiny certain.

To assist in the conrerance of this information, and accomplishing these objects, what channel so alpuropriate, what means so efrectire as the State $\Lambda$ gricultural Socicty, when it shall ocenpy the position and enjoy the ficcilities we claim for it?

'To place the society in this position, and in command of these ficcilities, liberal State aid will be required. The fiont door ot the State treasmy will have to be opened by the command of the people, and some of their money used tor the accomplishment of these objects. And why not? Facts and statisticis ane at hand to prove that no people erer became permanently prosperous, or State rich and powerful, until this policy was alopted and adhered to; and that no people or State erer adopted this policy, aud continued it judiciousls, withont beconing intelligent and happy, and rising high in the scale of individual and national greatness.

Fungland annually appropriates millions to amxiliary societics, similar to ours, for the encouragement of her agrienltural and manufacturing interests, and the world pars tribute to lier enterprise and prosperity. France, following ler example. has become a power upon the earth. Germany, by early arlopting this policy, has male herself an empire of knowledgre and a university to the world.

Imong our family of States, New York and Massachusetts are noble examples of an enlightened liberality. 'Then let California profit by good examples and be wise, as she would be grealt.

$W^{r}$ e diel intend to disenss another inportant question to California-the establishment of an Agricultural College. But tho space allowable in a report cmbricing so many oljects is not equal to the importance of the suhject. We, therefore, recommend the appointment of a Committee by our successors to take this sulject under consideration and report at some futuro time previnus to the meeting of the next Legislature.

111 of which is respectfully sulmitter.

I. N. IIosG, Secretary". ¿'HARLES F. REED, Presilent. 


\section{SYNOPSIS OF FINANCIAL REPORTS FOR 1864.}

Amount of cash receired from all sources (no appropriation from the State).....

Current expenses......................................\$10,591 03

Paid for warrants on General Fund................. 2,461 97

$\overline{\$ 13,05300} \overline{\$ 13,05300}$

INDEBTEDNESS OF SOCIETY.

Amount of warrants outstanding against the General Fund, January 13,1864

Interest on the same from date of registry to January $13,1865 \ldots . . \quad 1,22083$

Indebtedness at last date..........................................\$19,747 37

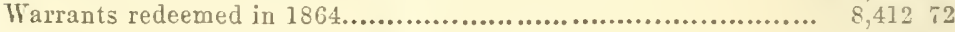

Present indebtedness................................................ $\$ 11.33465$

The Financial Report haring been referred to a committee, was found correct, and adopted by the Society.

\section{ELECTION.}

The terms of office of the President, C. F. Reed. and of Directors Richardson, Beck and Walsh having expired, by limitation of law, the same parties were re-elected-the President for one year, and the Directors for three.

At a meeting of the Board, held immediately after the adjournment of the annual meeting, 1. X. Hoag was unanimously re-elected Secretary of the Board, and R. T. Brown was elected Treasurer, Vice Coleman, resigned.

\section{CONSTITUTION.}

The Constitution of the Society was materially amended at the annual meeting. The more important changes will be found in the following extracts.

$$
\text { ARTICLE III.-Wemberships. }
$$

Section 1. Any person who has during the year 1865 , or who shall hereafter pay to the Funds of this Societr, the sum of Five Dollars. may become a member of the same; such membership to expire on the 31 st day of the following December.

\section{ARTICLE IV.-Officers.}

Section 1. The Officers of the Societr shall consist of a President and nine Directors, who shall constiute a State Board of Agriculture-fire of whom shall constitute a quorum. They shall elect a Treasurer and Secretary, not members of the Board. They may also appoint annually as Officers of the Board, a Chemist, a Botanist, a Geologist, a Metallurgist, a Meteorologist, a Zoologist and an Entomologist, and define the duties of each. They may appoint such Committees on the rarious departments of Agriculture, Mining and Manufactures, either generally, or for specific purposes, as they may deem important for the best interests of the state. and require such committees to report the result of their observations and investigations to the Board, at such times as may be named by them. 


\section{IMPORTANT BUSINESSS OF THE BOARD.}

At a meeting of the State Board of $\Lambda$ griculture, held at the Secretary's Office, on the $22 \mathrm{~d}$ day of Fehruary, 1865, it was determined to fill by appointment, the oflices named in the Seetion of the Constitution last above quoter, and the Secretary was authorized and empowered to select proper persons aud make such appointments, and also to appoint Committecmen in the sevcral bepartments named.

The following Rules were adopted, declaring the objects of such offiees, and defining the duties of the appointees.

\section{RULE I.}

The oljects of the office of Chemist to the Board, shall be the advancement of Agricultural knowledge, by the application of chemical science to the qualitative and quantitative analysis of Agricultural materials, such as soils, grains, fruits, manures, etc.; all chemical investigations of such officer for the Society shall be to this end, and shall be the property of the Society.

It shall be the duty of the Chemist to gire upon application, his written opinion to the Board, upon the adaptation of any soil to any particular kind of production, and vice versa, or upon any subject pertaining to Agricultural Chemistry, as embraced in the duties of his office. He shall keep a complete record of all his official transactions and opinions, and shall each year report the same to the Board, together with such suggestions and obserrations, as his experience may dictate for the adrancement of the Agriculture of California.

\section{RULE II.—oF BOTANIST.}

To obtain for record in the transactions of the Society, a full and popular description of the botanical productions of the State, both native and imported. To investigate and illustrate the plysiology of plants and trees, and the adaptation of the most useful, particularly the rarieties of forage plants, to our differeut localities and soils. To discuss and teach the importance and means of preserring the forests of our mountain districts, and to induce the eultirintion of woodlands by the agriculturalists, about their homes on our rich plains and prairies.

It shall be the duty of the Botanist to labor for the accomplishment of these objects, to assist in the collection of an herbarium at the Society's rooms, and to report annually a full account of his official transactions, including such suggestions as he may deem proper to make upon this branch of the State's natural history.

\section{IRULE III.-OF GEOLOGIST.}

Toobtain for publication a description of the general and Agricultural Geology of the State, with particular reference to the mineral and agrieultural advantages, in language ind style adapted to the general reader. The colleetion, classification and prescrvation, at the Rooms of the Society of specimens of the different kinds of rocks, minerals, fossils and soils,

The Geologist shall report annually to the Board, the progress of his work, and mako such recommendations is the interests of this department may require.

\section{RULE IV.-OF METALLERGIST.}

To keep for annual publication a correct and oflicial record of the various modes of mining in this State, and of reducing and separating the dillerent hinds of metals from their ores, and other matters. To note the improvenents male in the processes of such reduction and separation, and also the improvemeuts iu the machinery used for miniug purposes. To collect and place in 
the Society's cabinet, specimens of all kinds of ores, and of the metals in the different stages of reduetion.

The Netallurgist shall keep the record and perform the duties abore indicated, and report annually to the Board the work performed, and give a general review of the progress of mining in this State, and such statistics as he may be able to collect, pertaining to the same, with such observations for the general adrancement of this branch of industry as he may deem important.

\section{RULE V.-OF METEOROLIGIST.}

To keep a record of the various meteorological phenomena, such as the pressure, the temperature, and moisture of the atmosphere; also, the quantity of the rain at as many localities in the State as practicable.

The IIeteorologist shall keep or superintend these records and report them to the Board annually, accompanied by sach practical observation of their application to agricultural operations as may he suggested by his experience.

RULE TI.—oF ZOOLOGIST.

To obtain a description of the animals and birds of the State, and their habits, particularly those that are detrimental or benefieial to agriculture and horticulture. The collection, classification and preserration, in the Society's IIuseum, of stuffed specimens of all the native rarieties of birds and of such animals as may be deemed important.

The Zoologist shall prosecute the abore objects and make to the Board an anuual report of the progress of the work, including any recommendations for the preservation of the useful, or destruction of the injurious, as may be called for.

\section{RULE VII.-OF ENTONOLOGIST.}

To describe the Insects of the State, their habits and peculiarities, particularly those varieties destructive to vegetation. To collect, classify, and preserve, at the Society's Rooms, specimens of the different rarieties, and report annually to the Board any observations or suggestious upon their relations to agrieultural economy, and the means of preventing their ravages by their destruction or otherwise.

All reports indicated abore, and also all Reports from the Committees that may be appointed to report upon the several branches of industry indicated in the section of the Constitution abore quoted, to be made in writing to the Secretary of the Board, on or before the first day of December of each year, so that they may be properly arranged in the transactions of the Society, to be reported to the Governor by the first of January.

\section{STATISTICS FOR 1865.}

The Secretary has carefully prepared blanks for the collection and report of Statistics of all the more important Agricnltural productions of the State, and sent them out to all the County and District Assessors, accompanied by the following circular. IIe has already receired answers from a large number of the Assessors, saying they will cheerfnlly comply with the request, and the Board entertain a confident hope that they will thus be able to obtain a fnll and accurate table of the productions of the jear. They call on the Press and the public generally, for their co-operation in the premises.

$$
\left.\begin{array}{c}
\text { [circular.] } \\
\text { Rooms of the State Agriccliteral Societr, } \\
\text { Sacramento, February } 7,1865 .
\end{array}\right\}
$$

\section{To the Assessor of - -}

Dear Sir:-The State Board of Agriculture are rery desirons of obtaining through some reliable channel full and correct Agricultural Statistics of the State for 1865 .

They beliere there is no other way in which a citizen cau render so valuable 
n service to the State as in aiding them in the acromplishment of this object. 'They nlso belicre that the Assessurs of the several districts and eounties, from the muture of their duties, possess grenter facilities for collecting such statistics than any other jersuns; and that the eorrect business hinbits necessarily possessed hy a person to whom his fellow citimens have entrusted so important dutics as those of $A$ ssessor, will give to statistics collected hy him tho stump of chatracter and reliability. For the above reasons the lisaril have instructed me to request you to atd then in this undertuking. Believing that yon will cheerfully consent to do so, I have carefully prepared the accumpunying blanks for the collection of such statistics as are indicatcul in them, nnil those on the opposise side ol this sheet for your return of the sane in a condensed form, to this office. None but the most important and easiest obtitined are called for. The nmmlier of neres sown of the different kinds of crops, the uumber of trees planted of the dillerent larieties, and so on, you can obtain very easily by fastening the collecting blanks in your assessing honk which you cnrry wth you, and questioning parties as you assess them.

The amount of the productious for 1865 you can not obtain for the resson that you will have finished youl cunvass before most of them will be matured and githered. But as you are canvassing you can notice the appearance of the crops and hy conversation with farmers genera!ly you can obtain such information as will cuable you to make a very correct estimate of the average bushels of the different crops per acre, and, haring ohtained by canvass the number of acres sown to each, yon can casily estimate the whole product of your district or county. Hence the blank return sheets, in addition to the number of acres sown, eall for the estimated products of 1865 . It has heen customary: with those who have given any attention to this matter heretofore, to gather the produeds of the yeitr preceding the one in which the number of acres suwn or planted, was gathered. We beliere this custom has destroyed to a great extent the value of the tables thus formed, by apparently depreciating the productiveness of our soil. The aggregate products of such an exhibit, being less compred to the whole number of acres cultivated than the fuets wouhl show. Uur plan will correct this error, and by continuing it we ean arrive at an almost positive certainty, as next year the nssessor ean gather the actual produces of this, and thus test the correctness of your estimates.

The return sheet has also a place for the estimate of unenumerated productions. Your District or County may produce articles not enumerated, which you may deem important to make a record of. If so, you will enumerate and return them. There are many items, however, which we ean ohtain from the ["nited States Assessors and shall do so. We would like to have you also give an concise statement of the general resources and advantages of your County, whether agricultural, inineral or manufacturing. All the facts thus furnished will be cmbodied in the reports of our transactions to the next Legislature.

In $\mathrm{w}$, to the compensation for the services we ask of rou: The Boaril offer a premium of Fifty Dollars for the best statistienl and deseriptive report, and Twenty-five Dollars for the seconl best-the Bo:trd to be, or to select the Julges, unt the money to be patil as soon as the reports are received and exnmined. In atdition to this, careh Assessor who shall make a report to the Bo:tril as requesteml, will he voted a member of the State Agrieultural society, aml shall receive free all puhlications of the Society, and copies of such as are receivel of the (ieneral Govermment for distribution.

The lioard will also eulearor to ohtain from the next Legislature, and they have no doulut they will be succestiul, an uppropriation to pay you for the serviees you may perform this rear, and an annual appropriation for the contimume of such services in the future.

l'lase ackuowledge the receipt of this immeliately, and say whether you will perform the duties reguested, and wheiler you hive received a copy of our transactions for $1 \mathrm{sb3}$, which we mated for you. 
If you need more blanks at any time write for them. You will find postage stamps and envelopes for your correspondence and returns enclosed.

We shall want your reurns, and we presume you can make them, by the 1st or 15th of September. By order of the Board.

Very respectfully your obedient servant,

I. N. HOAG, Secretary State Board of Agriculture.

\section{TO THE PEOPIE OF OAIIFORNIA.}

The State Agricultural Society, by the organization of a corps of eminent scientific gentlemen, is now prepared to take the lead and give aim and direction to the development of all the rarious resources of the state, by the experimental and scientific investigation of every subject pertaining to the agricultural, manufacturing and mining interests.

Also, to contribute in an authentic and official manner, to every branch of the natural history of the State, by the collection, classification and preservation of facts and phenomena in the meteorological world, and of specimens from our geological, botanical and animal kingdoms.

$\mathrm{By}$ enlisting the co-operation of the county and district assessors of the State-the assessors of internal revenue, and business men generally, it is proposed to collect and preserve a full and complete record of the productions of all our industrial pursuits.

Our Chemist and Metallurgist, Dr. R. Oxland, Professor of chemistry in the Toland Medical College at San Francisco, is prepared to make correct assays of the different metals, as gold, silver, copper, iron, tin, etc. Also, to analyse different kinds of manures and soils, and petroleum, asphaltum, bitumen, etc. He has had a large experience in the manufacture of sugar from beets, and refining the same, and in agricultural and manufacturing chemistry generally, and is prepared to give instruction in all these departments. For any work done in any branch of his department, members of the Society will be allowed twenty per. cent discount from the ustual prices.

Dr. Kellogg and Prof. Borlander will analyse and elassify any specimens of regetable productions forwarded to them. Prof. Borlander has given much time to the study of the grasses, and Dr. Kellogg to the floral department of Botany.

Dr. Behr may be consulted upon the insects, and Dr. Cooper upon the animals, birds and reptiles of the State-both having giren these specialties much time and attention. are prepared to give correct information.

Dr. Logan will investigate any atmospherical phenomena, or climatic changes, to which his attention is called. Records and observations heretofore published by him testify the soundness of his knowledge.

The abore gentlemen have all been consulted personally by the Secretary, and have each accepted the position to which he has been appointed.

Prof. Whitney is not in the State, but his friends give assurance that he will accept the position, and give his eminent abilities to the success of the enterprise.

Committees in all the departments of agriculture will be appointed as soon as the right men can be secured. A premium list for the Fair of 1865, emhracing every industry in the State, will be published as soon as it can be completed.

The Board call upou the people and the press of every county in the State, for their earnest and practical co-operation and support-and they doubt not they will receive it. Geological, inetallurgical, botanical, zoological, and entomological specimens, and curiosities of every hind, are solicited for the cabinet and museum, and may be forwarled to the Secretary through Wells, Fargo \& Co.'s Express, free of charge. By Order. I. N. HOAG, secretary. 

